\title{
THE CHALLENGES OF IMPLEMENTING SOCIAL MEDIA MARKETING IN THE TOURISM INDUSTRY: A SYSTEMATIC REVIEW
}

\author{
Nawal Nasser Al-Haidari ${ }^{1}$, Salah Kabanda ${ }^{1}$ and Maryam Meshari Almukhaylid ${ }^{2}$ \\ ${ }^{1}$ University of Cape Town, South Africa \\ ${ }^{2}$ King Faisal University, Saudi Arabia
}

\begin{abstract}
Tourists consider social media platforms invaluable tools for travel planning. Social media serves as a major resource that provides consumers with useful information when organizing holidays, and that helps tourism businesses to deliver content for commercial marketing purpose. Tourism SMEs (Small and Medium Entrepreneurs) face challenges that inhibit the growth of implementing social media for marketing purposes. This paper, which is based on a systematic literature review of 181 academic journals, identifies the key challenges that hinder SMEs in the implementation of social media marketing in their business. This study reviews and analyses all extant social media-related research articles published in academic journals during 2010 to 2020, mainly in tourism, hospitality fields. Research findings thoroughly demonstrate the key challenges of implementing social media for marketing in the tourism industry. There are two main challenges that SMEs experience. The first category is organisational challenges, which include an uncertain return on investment and a lack of credibility and reliability as an information source, lack of technological knowledge, issues around social media presence, time constrains, and the failure to define marketing objectives. The second category is environmental challenges, which include empowered tourism consumers, competitive business environments, and the fear of negative comments.
\end{abstract}

\section{KEYWORDS}

Social Media, Web 2.0, Tourism, Hospitality, Marketing

\section{INTRODUCTION}

Social media has become an important part of our daily lives, as we move our communication to virtual platforms like LinkedIn, Instagram, Facebook and Twitter (Alalwan, Rana, Dwivedi, \& Algharabat, 2017). Social media has proven its worth not only as a tool for virtual socializing, but also as a valuable business resource (Hassan, Nadzim, \& Shiratuddin, 2015; Law, Leung, Lo, Leung, \& Fong, 2015; Meredith, 2012). Social media is perceived as a powerful marketing tool for its ability to be interactive. Within the tourism industry, it provides opportunities for a rapid response to customers' demand and changes in the marketplace (Lim, Saldana, \& Saldana, 2011). Customers are sharing information through social media about their experiences with products and services, including information about hotel accommodations and facilities. This sharing of information is now viewed as new sources of market intelligence (Lim et al., 2011).

As technological capabilities increase within social media, destinations are competing more and more for the attention of travellers, resulting in a stiffening of competition in the global market of tourism (Roque \& Raposo, 2016). The fact that tourism is an information-intensive industry has boosted the growing use of social media (Roque \& Raposo, 2016). For this reason, many tourism organisations turn to social media as a relatively low-cost and global reach marketing tool (Hays, Page, \& Buhalis, 2013). They take advantage of this web-based tool for sharing information, promoting products and services, and communicating directly with customers. A new light has been shed on social media as organisations see possible benefits such increased visibility, directly engagement with consumers, and being able to remain competitive (Canovi \& Pucciarelli, 2019).

Despite the significant and continued usage of social media in the tourism industry, Small and Medium Entrepreneurs (SMEs) still face challenges on how best to use social media for marketing purposes (Howison, Finger, \& Hauschka, 2015). This is partly because of the limited studies that shed light on the challenges 
constraining the implementation of social media for marketing purposes within the tourism industry (John, Larke, \& Kilgour, 2018). To address this challenge, this paper seeks to consolidate current literature on social media-related research. By identifying these challenges, SMEs will develop strategies to overcome them, and also seamlessly implement social media for marketing purposes (Matikiti, Mpinganjira, \& Roberts-Lombard, 2018). Additionally, SMEs lag behind large tourism businesses in implementing social media marketing (Matikiti et al., 2018). By using social media marketing, SMEs will improve their marketing efforts, and consequently increase their customer base, gain social, economic and emotional value from the use of social media platforms (Canovi \& Pucciarelli, 2019), as well as a competitive business edge.

The purpose of this paper therefore is to identify the challenges SMEs in the tourism industry face when implementing social media for marketing purposes. This field of study is important, especially for organisations in emerging economies where some identified challenges can be adequately addressed if social media is rightly implemented. On this note, the key research question which the study seeks to address is "What challenges do tourism SMEs face when they embark on implementing social media for marketing purposes?". To answer this question, the study will follow the systematic literature review guidelines presented by Okoli and Schabram (2010). These guidelines are essential to ensure a scientifically rigorous review, particularly tailored for information systems research as well as to respond to the field's balance of quantitative and qualitative methodologies (Okoli \& Schabram, 2010).

\section{RESEARCH METHOD}

\subsection{Research Approach}

This paper seeks to synthesize and examine the challenges SMEs in the tourism industry face when they embark on implementing social media for marketing purposes. The researcher has conducted a systematic literature review of academic journals following Okoli and Schabram (2010) guidelines. The guidelines include the identification, evaluation, and synthesis of existing academic articles (Okoli \& Schabram, 2010). These guidelines were adopted because they were designed for IS research to ensure rigor and reproducibility (Okoli \& Schabram, 2010).

\subsection{Data Collection}

Data collection commenced in February 2020. Data was collected from the major databases: "Google Scholar" and "Web of Science". Google Scholar and Web of Science are used to cover literature which are the most relevant as these databases frequently used for IS literature reviews (Bandara, Furtmueller, Gorbacheva, Miskon, \& Beekhuyzen, 2015; Schryen, 2015). Only papers written in English and only those from the period $2011-2020$ were chosen for this study because mapping literature should be aimed at past studies going back 10 years as recommended by Oosterwyk, Brown, and Geeling (2019); Templier and Paré (2015). Data was collected using the following key terms "social media" and "social networking", "web 2.0" and "user-generated content". Further key terms used included "marketing" AND "tourism OR tourist* OR hospitality". Data collection was in three phases. In the first phase, Google Scholar was used to identify all literature related to the relevant topic. The Google Scholar search terms included the keywords of "tourism" or "hospitality" in the "with all of the words" box, "social media OR social networking OR web 2.0 OR user-generated content" in the "with at least one of the words" box. This phase yielded 159 articles.

The Second phase of data collection was conducted using the Web of Science database from the combined search of the basket of top eight journals in Information Systems (IS), and the top ranked tourism and hospitality journals. The basket of IS journals were identified by reference to the AIS Top 8 with reference to Lowry et al. (2013). The basket of eight leading IS journals includes (European Journal of Information Systems, Information Systems Journal, Information Systems Research, Journal of Association of Information Systems, Journal of Management Information Systems, MIS Quarterly, Journal of Strategic Information Systems and Journal of Information Technology). The top journals on tourism and Hospitality were identified by reference to Gursoy and Sandstrom (2016). These included the Journal of Travel Research, Tourism Management, Annals of Tourism Research, International Journal of Hospitality Management, and Journal of Hospitality \& Tourism Research. We have used the same key terms "social media" and "social networking", "web 2.0" 
and "user-generated content". Further key terms used included "marketing" AND "tourism OR tourist* OR hospitality", in "Titles". However, the journal articles were limited and surprisingly yielded only one result (Cimbaljevic, 2015). For this reason, all available other fields in Web of Science were added. The purpose of the third pass was to look for additional relevant journal papers and further data. Finally, in the third phase of data collection, the search resulted in 22 journal articles from Web of Science. Thus, based on the previous phases, the total number of papers from the data collection stood at 181. Each of these journal articles became the data corpus for the study as shown in Figure 1.

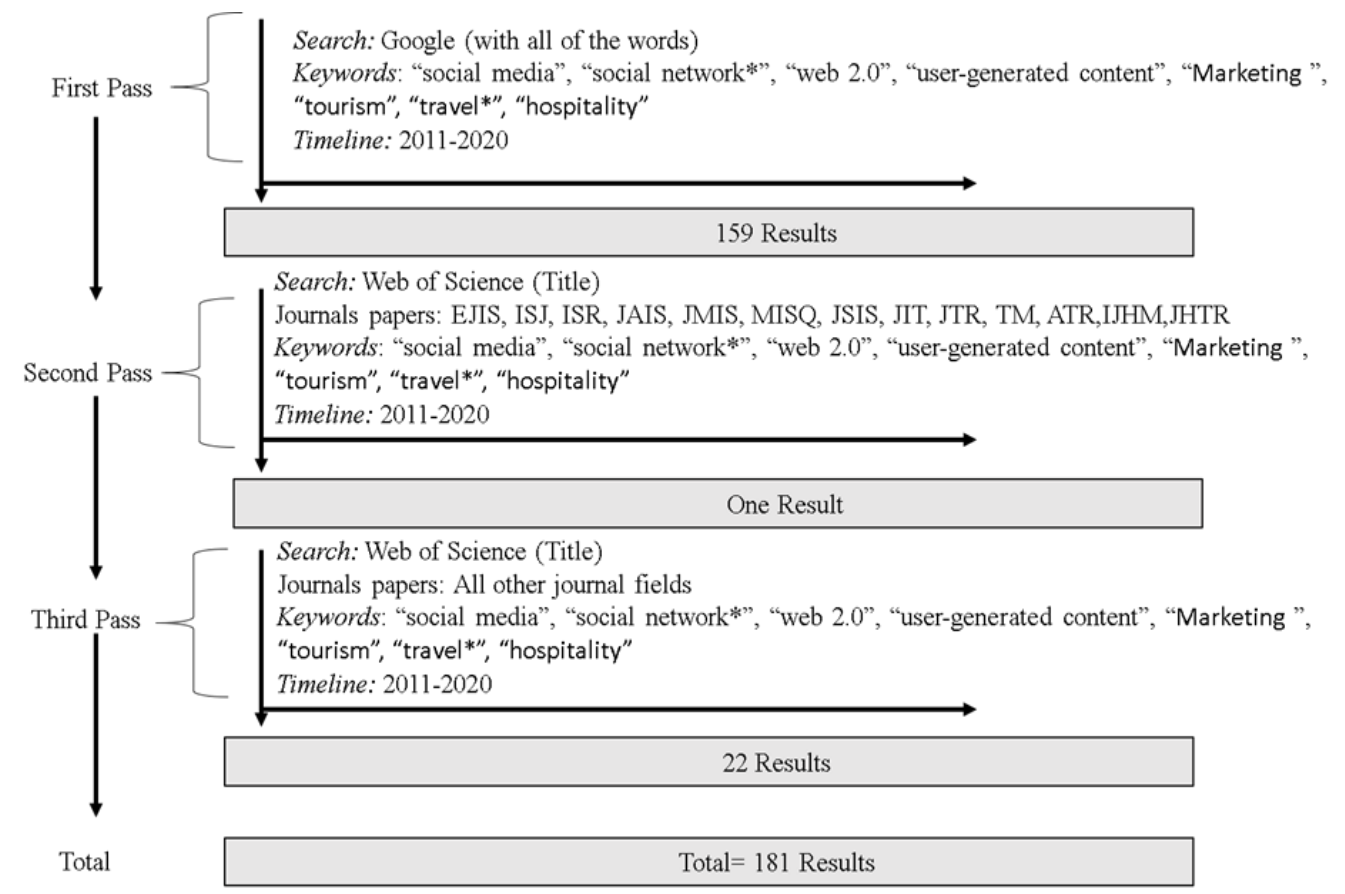

Figure 1. Search and selection of articles

\subsection{Analysis}

\subsubsection{Preliminary Analysis}

After the previous process, the journal articles from the two different sources were imported into Excel, recording the article attributes. The following was recorded for each paper: author(s), paper title, publication year, publication source, keywords, and abstract. Then, each article was screened to ensure that the article did indeed cover the social phenomenon of social media marketing and associated implementation challenges. While doing this analysis, it was observed many of the articles were duplicates, thesis, or reports. Others were articles not written in English. For example, the article by John et al. (2018) was repeated from two different sources, in Web of Science and Google scholar search engines; whilst Camilleri (2016) appeared as an article but was actually a Bachelor's thesis. Articles that were in this category were removed from the data corpus, reducing the total number of articles from 181 to 47.

\subsubsection{Practical Screening}

The next stage of the analysis started by reading each of the articles to understand the article's relevance to this study. Using the "Practical screening" process of inclusion and exclusion criteria, the researchers removed irrelevant articles and some publications that did not principally focus on challenges of implementing social media marketing in tourism and hospitality. For example, the article by Borden (2017) was excluded because it did not relate to the study. The article shows how initiatives are encouraging water efficient behaviour among guests developed through the process of social marketing with smaller firms. Based on a review of the title, topic, keywords, abstract, introduction and conclusion of the articles, 47 publications were retained for full reading and 39 for the final analysis. 


\subsubsection{Thematic Analysis}

After the practical screening, the remaining articles were entered into NVIVO software for the thematic analysis stage. The purpose was to identify key emergent themes associated with implementation of social media for marketing purposes in SMEs in the tourism industry. Using NVIVO may significantly improve the quality of research. The reasoning for the use of this software is based on its ability to assist the researcher in the identification of themes as well as saving time due to the management of a large number of articles (Hilal \& Alabri, 2013). Emergent themes generated from common patterns in the data corpus are shown in Table 1.

Table 1. Empirical findings of social media marketing implementation challenges

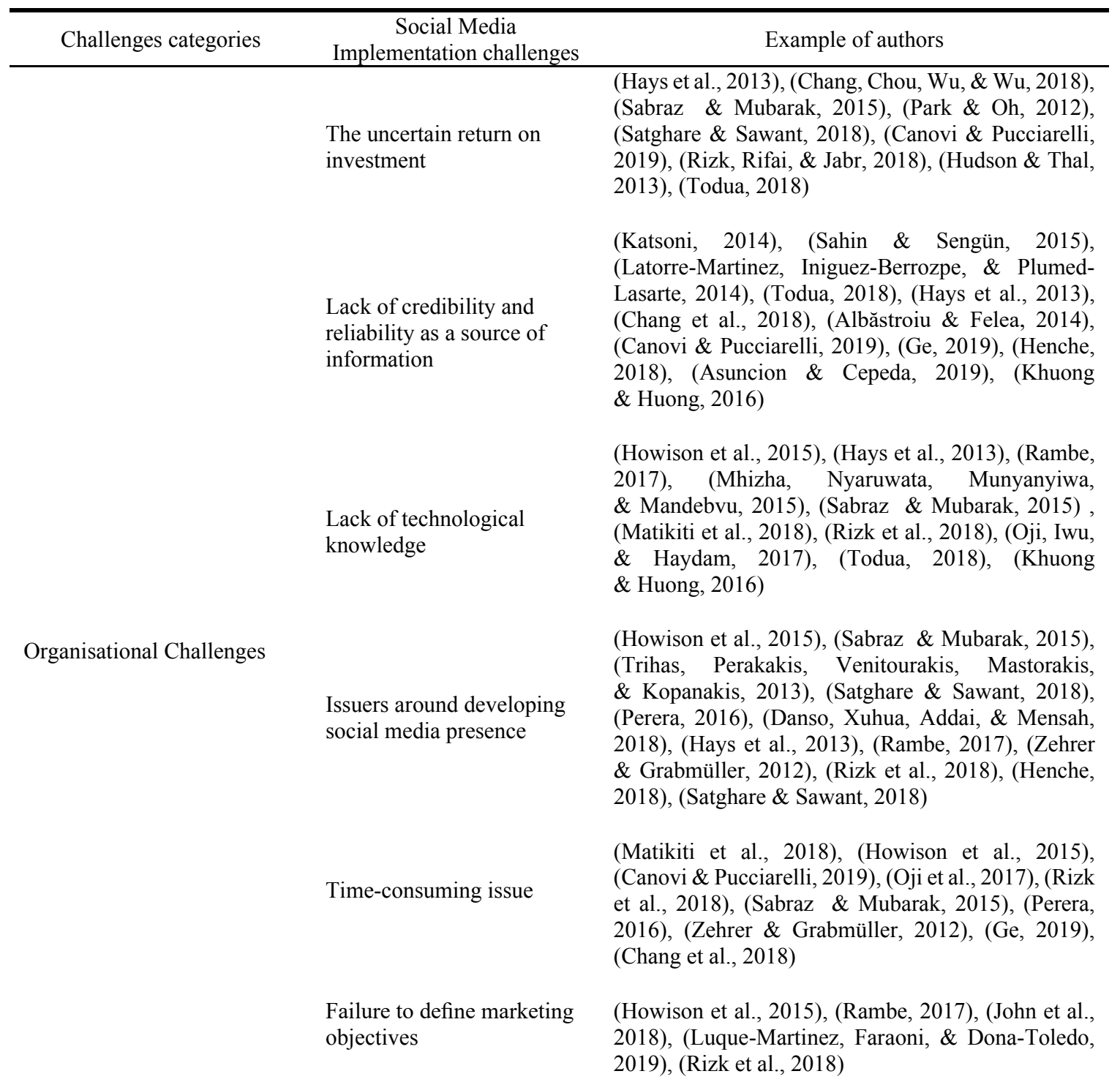


Empowered tourism consumers

Environmental Challenges
Competitive business environment

(Howison et al., 2015), (Danso et al., 2018), (Hays et al., 2013), (Roque \& Raposo, 2016), (Khuong \& Huong, 2016), (Jaelani, Erdinaya, Rohanda, \& Perbawasari, 2019), (Kumar, Kumar, \& Mishra, 2015), (Sabraz \& Mubarak, 2015), (Vaid \& Kesharwani, 2018)

(Zamani, 2016), (John et al., 2018), (Howison et al., 2015), (Huang, 2012), (Hays et al., 2013), (Trihas et al., 2013), (Mhizha et al., 2015), (Rambe, 2017), (Perera, 2016), (Hsu \& Ou Yang, 2013), (Sabraz \& Mubarak, 2015), (Lim et al., 2011), (Todua, 2018), (Danso et al., 2018), (Vaid \& Kesharwani, 2018), (Rizk et al., 2018), (Katsoni, 2014), (Park \& Oh, 2012)

(Sahin \& Sengün, 2015), (Tsiakali, 2018), (Canovi

Fears of negative comment (Stojanović \& kurtić, 2019), (Rizk et al., 2018), $(\mathrm{Ge}, 2019)$

\section{FINDINGS}

\subsection{Organisational Challenges}

The results of this study showed that six organisational challenges emerged from the results of our systematic literature review. They are as follows: The uncertain return on investment, the lack of credibility and reliability as an information source, lack of technological knowledge, issues around developing social media presence, time constraints, and failure to define marketing objectives.

\subsubsection{The Uncertain Return on Investment}

The findings show that nine articles identified uncertain return on investment as a challenge influencing the implementation of social media marketing in the tourism industry. Articles included in the research were taken from countries such as India, Korea, Italy, Lebanon, Taiwan, the USA, and the UK. Up to 75\% of articles followed the qualitative method. The consistent issue identified by all SMEs was the inability to measure the return on investment (ROI) once they have adopted and used social media for marketing purposes (Park \& Oh, 2012). For example, Hays et al. (2013) indicate that marketers are under pressure from their companies to measure everything they do on social media, and it is difficult to measure revenue with the traditional ROI approach because this requires qualitative measurement. In addition to not knowing how to measure ROI, several studies see no direct evidence to justify the investments in social media as a marketing strategy (Chang et al., 2018).

\subsubsection{Lack of Credibility and Reliability as an Information Source}

A lack of credible and reliable information sources was seen as an issue that most SMEs experience (Katsoni, 2014). Twelve articles related to this finding show that a lack of credibility and reliability as an information source concerning social media marketing in Europe and South-East Asia. Countries such as Spain, Georgia, Italy, Romania, Madrid, Philippines, Vietnam, and Taiwan were affected. In tourism marketing accounts on social media, the most commonly seen unethical content is exaggerated and misleading information, as well as insufficient information about the goods and services of the destination or tourism firms (Sahin \& Sengün, 2015). The multitude of false information can cause erroneous choices (Albăstroiu \& Felea, 2014). Tourists who use social media are influenced by comments and information that can be found on social media, whether they are positive or negative. The reliability of tourism organisations depend on these comments (Sahin \& Sengün, 2015). Negative comments and false information contribute to a bad brand image, which results in a lack of trust and reliability as a source of information. Additionally, what is shared among users on social 
media generates confidence and more credibility than official information from tourism organisations and has therefore become a valuable aspect in tourism decision-making (Henche, 2018). However, tourism SMEs should be consistent in posting as much rich content as possible, and including different types of information, such as links, photos, videos, and websites. This will reinforce the range, richness and reliability, while providing the necessary information to their consumers (Chang et al., 2018; Hays et al., 2013). Tourism SMEs should be aware of how they interact with users online, especially users who spread negative messages on social media. Other potential tourism users are watching and can be easily swayed by such feedback (Asuncion \& Cepeda, 2019). Todua (2018) has reported that social media marketing of tourism organisations has a great impact on the interest, reliability, and satisfaction of the consumer. It also was suggested by Ge (2019) that tourism SMEs could use humor to create marketing campaigns appealing messages with their users for supporting and enhancing the credibility of communicators on social media marketing. Tourism SMEs should be aware that social media allows not only for promoting goods and services, but also to communicate with users and build trust and credibility which can enhance brand awareness (Canovi \& Pucciarelli, 2019). Despite the fact that social media has many marketing benefits, tourism organisations have a lack of reliability when using social media as a source of information for market studies (Latorre-Martinez et al., 2014).

\subsubsection{Lack of Technological Knowledge}

The findings identify ten articles that have shown that the lack of technological knowledge of the use of social media for marketing purposes have an impact on tourism SMEs experiences. Articles with an African research context, specifically those from South Africa, identified this as a challenge more than articles from the South Asian region. SMEs are struggling to understand the value of social media for their business (Howison et al., 2015; Rizk et al., 2018) due to the lack of understanding of social media platforms and their uses related to the tourism industry (Hays et al., 2013; Howison et al., 2015; Rambe, 2017). The relationship between the use of social media marketing and the intention of continuing social media marketing, is moderated by technological knowledge (Matikiti et al., 2018). Some SMEs use social media only to maintain a profile, which shows SMEs' lack of understanding when it comes to the use of social media (Howison et al., 2015). Lack of technological knowledge and capacity impedes SMEs' ability to take full advantage of using social media (Matikiti et al., 2018; Mhizha et al., 2015). In some cases, resistance to using social media was discovered, as it was not considered an effective tool (Howison et al., 2015). This challenge has resulted that SMEs have a lack of confidence and trust in such technologies (Rambe, 2017). The lack of understanding around social media platforms and its use related to tourism, especially in developing countries, such as Georgia, South Africa, and Lebanon, should be noted (Oji et al., 2017; Rizk et al., 2018; Todua, 2018).

\subsubsection{Issues Around Developing Social Media Presence}

Twelve articles have identified the issues surrounding social media presence development as a challenge. Articles reported this challenge from Southern Asia more than Europe. Only Lebanon from the Middle Eastern region have reported this finding. It is important for tourism SMEs to develop cost-effective approaches to the use of social media marketing (Howison et al., 2015). Tourism SMEs' limitations related to time and expenditure are well understood. Therefore, developing a social media presence would help them to increase awareness of their business and to generate sales in ways that do not require extensive human resources (Howison et al., 2015). Tourism SMEs need to improve the use of social media by actively presenting themselves and engaging with the other users; in this way, they will be able to increase awareness of their products and services to potential consumers (Howison et al., 2015). Real-time updates are also important for tourism SME as well as responding quickly to inquiries on social media are imperative. Consumers need to feel "safe" in their travel decisions before, during, and after their trip (Howison et al., 2015; Tsiakali, 2018). However, some of the SMEs' cases consider discontinuing their presence on social media (Sabraz \& Mubarak, 2015). They feel the pressure from the customers on their business' profile while others fear the status of their brand can be damaged by the customer's negative comments on social media (Sabraz \& Mubarak, 2015).

\subsubsection{Time Constraints}

Ten articles have mentioned the time constraints of using social media as a challenge for tourism SMEs (Matikiti et al., 2018). Up to 50\% of the articles that highlighted this were from South Africa and Sri Lanka. It is also important to commit to the use of social media for marketing purposes to develop online marketing campaigns (Howison et al., 2015). SMEs should consider the time required to update and post new information 
online, as well as the time spent on social media (Howison et al., 2015). In Canovi and Pucciarelli (2019) study, they mentioned the time constraints are one of the major challenges that winery owners experience regarding the use of social media in marketing and their promotion of wine tourism online. Winery owners explained that they feel pressured from consumers/tourists to use and constantly update their social media platforms often. They are struggling to commit to the adoption of social media because it is time consuming and this is taking the focus away from the core activities of the winery, such as tourist visits and wine tastings.

\subsubsection{Failure to Define Marketing Objectives}

Five articles have found that many tourism SMEs failed to design and implement a successful social media marketing strategy because they failed to define their marketing objectives (Howison et al., 2015). Some tourism SMEs measure online marketing activities, but they do not know what to do with the collected data. It is therefore necessary for SMEs to define their marketing objectives and to develop their social media marketing strategies based on what their business wants to achieve.

Additional organisational challenges include limited financial and human resources (Canovi \& Pucciarelli, 2019; Chang et al., 2018; Hays et al., 2013; Oji et al., 2017; Rambe, 2017), resistance to change (Matikiti et al., 2018), and top management support issues (Matikiti et al., 2018; Sabraz \& Mubarak, 2015).

\subsection{Environmental Challenges}

\subsubsection{Empowered Tourism Users}

Social media enables the users to share their travel experience, reviews, photos and videos which switch the control from tourism SMEs to tourism consumers (Danso et al., 2018; Howison et al., 2015). The findings show nine articles highlighted that tourism organizations have no ability to control the tourism content posted on social media and they do not determine when, where, or if the user consumes the information available on social media. Most of the countries that found this challenge were from South Asia, such as India, Sri Lanka, Vietnam, and Indonesia. Tourism users gain the power to influence other consumers in the marketing process, while tourism companies no longer have ultimate control over the brand image of a destination or products (Danso et al., 2018; Hays et al., 2013; Roque \& Raposo, 2016). It has been reported by Sabraz and Mubarak (2015), that one of the senior managers of a tourism firm lost the control of their brand image to the hands of customers. He contemplated discontinuing social media marketing due to the pressure from the customers on their social media profile.

\subsubsection{Competitive Business Environment}

Eighteen journal articles have reported that tourism organisations are forced to use social media and implement their marketing activities to gain a competitive advantage. This is a crucial challenge that tourism SMEs face when they implement social media marketing in a competitive business environment (Zamani, 2016). Nowadays, more consumers are engaging on social media than they did in the past. Therefore, tourism SMEs need to enhance the destination image brand differently from competitors (John et al., 2018). In Taiwan, tourism SMEs are struggling to build a brand image that enables them to easily sell their products and services (Huang, 2012). They use social media to market their business and to differentiate themselves from their competitors. Tourism SMEs that do not adopt and implement social media for their marketing, will not have the competitive advantage (Hays et al., 2013; Trihas et al., 2013).

\subsubsection{The Fear of Negative Comments}

This is one of the common challenges which SMEs face when they implement social media marketing. Seven articles, especially from the European region, have reported the fear of negative comments as a barrier that hinders SMEs from implementing social media marketing strategies. As tourism products are mostly services, it is important to ensure high-quality service and to resolve any dissatisfaction amongst the guests (Sahin \& Sengün, 2015). Negative reviews decrease the sales as the consumers log in to social media to get market updates (Tsiakali, 2018). It is convenient for consumers to look for the tourism SMEs services on social media, and to search for reviews and comments from other travelers in order to reduce the risks and to verify the value, experience, and price of the products or services (Tsiakali, 2018). Slightly negative reviews and comments can affect the tourism SMEs' brand image, which prevents the SMEs from implementing social media marketing strategies (Sahin \& Sengün, 2015). However, while past studies explained this challenge for SMEs in a recent study by Canovi and Pucciarelli (2019), none of their participants mentioned such a challenge. 


\section{DISCUSSION}

The literature analysis shows that social media marketing implementation challenges are interlinked. The findings show that uncertain return on investment is one of the major challenges that hold tourism organisations back from investing in social media marketing because it is not quite straightforward. Park and Oh (2012) mentioned the difficulty when measuring revenue with the traditional ROI (return on investment) approach. Typically, the traditional ROI approach is defined as the net proceeds from an investment over its costs (Gould \& Nazarian, 2018; Kaske, Kugler, \& Smolnik, 2012, p. 3900). Since marketers only rely on finance metrics, this is insufficient to identify the return on marketing investment via social media (Kaske et al., 2012). In contrast, SMEs should learn from larger companies how to rate the return on their investment and which metrics they should use for social media marketing. In the Hays et al. (2013) study, they identified three key areas in which the destination marketing organizations evaluated their social media efforts. The key areas include audience size, degree of consumer engagement, and consumer sentiment. In the case of the KLA tour, they were able to measure the growth of brand awareness by using 'the valence of follower/fans' (Park \& Oh, 2012). Additionally, social media itself and other external web tools are used for analysing principles that could be used to determine the return on investment. It would benefit SMEs to have social media marketing strategies that increase their sales and enhance the business' competitive advantage.

Marketing on social media requires many skills such as technological knowledge, writing skills, an understanding of how content works on social web, measuring data for decision-making, and experience with digital tools, platforms, and channels. There is a need for a clear understanding of why social media is a vital tool and how social media can benefit SMEs. One of the reasons why tourism SMEs are resistant to using social media effectively, it because of the time constraints. The amount of time required to engage via social media is one of the major challenges that tourism SMEs face, the amount of time required for social media management, engaging with users, creating and posting content, and achieving social media marketing goals, can pose a challenge, especially for SMEs with smaller staff complements. A potential solution to consider when addressing time constraints is to consider hiring full or part-time social media marketing experts to manage all online marketing, given the lack of scarcity of experienced social media experts (Sabraz and Mubarak (2015).

Another school of thought demonstrates that empowered tourism users are closely linked to the fear of negative comments. In other words, the fear of negative comments can be seen as the consequence of empowered tourism users. As a result of digital word of mouth (users communicating with each other online), the SMEs have no control over the content on social media. Therefore, research into the strategic use of social media for marketing is a worthwhile effort. Slightly negative reviews and comments can affect the tourism SMEs' brand image, which prevents the SMEs from implementing social media marketing campaigns (Sahin \& Sengün, 2015). However, while past studies explain the fears of negative comments for SMEs, recently in the Canovi and Pucciarelli (2019) study, none of the participants mentioned such a challenge.

From this standpoint we can consider that misleading information and incorrect advertisement content are correlated to negative comments (Sahin \& Sengün, 2015). This is commonly seen in the use of social media in tourism marketing where many negative comments are made in order to mislead, exaggerate and provide partial information on the goods and services of the destination or tourism SMEs (Sahin \& Sengün, 2015). Additionally, the younger generation might share negative comments on social media (Sahin \& Sengün, 2015). Therefore, tourism SMEs should utilize social media effectively and provide solutions as soon as they enter the social media marketing process to protect their brand image (Asuncion \& Cepeda, 2019; Sahin \& Sengün, 2015). False information and irrelevant comments that could damage the brand's reputation can be dealt with in legal ways to protect the brand image from customers (Sahin \& Sengün, 2015). Moreover, SMEs need to analyse social media marketing performance, increase follower engagement, and encourage satisfied consumers to comment and share their travel experience on the business profile via social media, which can be done by sharing reliable information about the destinations, like popular attractions, travel tips, and so on.

Accordingly, the business brand image will suffer if they do not have any specific strategy or policies on social media marketing (Sabraz \& Mubarak, 2015). Without defining marketing objectives, tourism SMEs will struggle to follow the business's direction because it is not clear what their paths are. Marketing objectives are the foundation of any successful social media marketing strategy. They should be specific, measurable, achievable, realistic and timebound (Perera, 2016). Outlining marketing objectives, such as strengthening engagement to increase customer loyalty, developing brand awareness, monitoring customer feedback, and 
promoting new products and services, will help the business progress. Once the business outlines their marketing objectives, they should develop a detailed plan and align their marketing objectives with their business goals. This will improve efficiency with informed decision-making processes, and it will also help them to communicate effectively with their target audience. Additionally, it is important that marketing mangers keep up with social media trends and customers to redirect the business's effort towards customers' needs, problems, and desires (Moro \& Rita, 2018). In summation, without clear marketing objectives and business goals, social media marketing firms cannot lead businesses in the right direction. For instance, it is difficult to finance marketing activities when tourism products that align with audience interests have not yet been identified. The marketing needs to promote the correct products to the target audience, or the effort, time, and money spent on social media marketing will be wasted.

A competitive business environment is a crucial challenge that tourism SMEs face when they implement social media marketing in a highly competitive field (Zamani, 2016). Therefore, tourism SMEs need to enhance their business's image brand differently from competitors (John et al., 2018). Tourism SMEs should consider that consumers are more empowered now than they were in the past, because of how they receive marketing communication from other enterprises. Having a competitive advantage requires SMEs to understand the consumer's needs and to make the consumers feel that they have some control over the marketing messages they are receiving. Consumers are constantly searching for a balance between what organisations are saying about themselves with regards to their products and services, and what other consumers who have sampled those products and services are saying (Starkov \& Safer, 2011). The use of social media is a key tool to ensure that customers receive a balanced view of the quality and value for money of services and products offered by organisations in the tourism industry. However, having a presence on social networks is only the first phase of a social media strategy (Trihas et al., 2013). Tourism organizations with a dormant social media presence are generally perceived by their target audience as lacking credibility (Horn Nord et al., 2014). As a result, SMEs also face the significant challenge which is the lack of credibility and reliability as an information source. In contrast, tourism and travel information which are provided via social media is an essential source of information and is perceived to be more trustworthy than mass media (Abiola-Oke \& Aina, 2020; Islam \& Boro, 2019; Jaelani et al., 2019). In addition to information, there is a need for ongoing social engagement with customers using social media. Social media engagement increases loyalty and aids word of mouth. Being engaged with users is the key to building trust, nurturing relationships, and developing empathy, which in turn increases a tourism firm's credibility. Moreover, replying to negative comments is necessary, as it brings peace of mind to other potential tourists. Thus, ignoring negative comments could impact the tourism SMEs' brand image. The speed at which businesses respond is also important because users expect prompt responses from businesses on social media. Tourism SMEs should ask clients to share their experience and post feedback on social media. Therefore, tourism SMEs should utilize social media effectively and provide solutions as soon as they enter the social media marketing process to protect their brand image (Asuncion \& Cepeda, 2019; Sahin $\&$ Sengün, 2015).

To conclude, there is a need for more knowledge and qualified expertise to effectively use social media for marketing purposes in the SME context. Manger of travel agencies, tour operating businesses, and the tourism authorities in the government should support the use of social media marketing for small and medium tourism businesses through providing training and workshops on social media marketing for the staff (and owners) to acquire the necessary skills (Matikiti et al., 2018). Therefore, lack of proper marketing skills may result in SMEs' reluctance to exploit social media for marketing when SMEs lack the skills and expertise which negatively impact business survival (Oji et al., 2017). Tourism SMEs must define their marketing objectives to develop their social media strategies based on what their business wants to achieve. The present findings confirm the need to develop social media strategies which align with business objectives.

\section{CONCLUSION}

The aim of this study was to shed light on the challenges constraining the implementation of social media for marketing purposes within the tourism industry. Following a systematic literature review, the study showed two categories of challenges, namely organisational and environmental challenges. Organisational challenges include the uncertain return on investment, lack of credibility and reliability as an information source, the lack of technological knowledge, issues around developing social media presence, time constraints, and failure to 
define their marketing objectives. Environmental challenges include empowered tourism consumers, competitive business environments, and the fear of negative comments. These findings contribute to a better understanding of the challenges SMEs in low to middle income countries face when adopting or implementing social media for marketing purposes.

\section{REFERENCES}

Abiola-Oke, E., \& Aina, C. O. (2020). Effect of Online Travel Bookings and Social Media on Tourism Destination Marketing in Nigeria. Advanced Journal of Social Science, 6(1), 10-16.

Alalwan, A. A., Rana, N. P., Dwivedi, Y. K., \& Algharabat, R. (2017). Social media in marketing: A review and analysis of the existing literature. Telematics and Informatics, 34(7), 1177-1190. doi:10.1016/j.tele.2017.05.008

Albăstroiu, I., \& Felea, M. (2014). The implications of user-generated content websites for tourism marketing. International Journal of Economic Practices and Theories, 4(2), 222-229.

Asuncion, D. A., \& Cepeda, J. (2019). Surfacing Social Media as a Platform in Marketing Selected Tourism Establishments in Santa Rosa, Laguna. Journal of International Tourism and Hospitality Management, 4(2), 125-135.

Bandara, W., Furtmueller, E., Gorbacheva, E., Miskon, S., \& Beekhuyzen, J. (2015). Achieving rigor in literature reviews: Insights from qualitative data analysis and tool-support. Communications of the Association for Information Systems, 37(1), 154-204.

Borden, D. S. C., T.;Shaw, G. (2017). Social marketing, sustainable tourism, and small/medium size tourism enterprises: challenges and opportunities for changing guest behaviour. Journal of Sustainable Tourism, 25(7), 903-920. doi:10.1080/09669582.2016.1270952

Camilleri, J. (2016). The use of social media marketing in tourism enterprises in Malta. (Bachelor's thesis), University of Malta, Malta.

Canovi, M., \& Pucciarelli, F. (2019). Social media marketing in wine tourism: winery owners' perceptions. Journal of Travel \& Tourism Marketing, 36(6), 653-664. doi:10.1080/10548408.2019.1624241

Chang, H.-L., Chou, Y.-C., Wu, D.-Y., \& Wu, S.-C. (2018). Will firm's marketing efforts on owned social media payoff? A quasi-experimental analysis of tourism products. Decision Support Systems, 107, 13-25. doi:10.1016/j.dss.2017.12.011

Cimbaljevic, M. (2015). Social media marketing in tourism and hospitality. Annals of Tourism Research, 54, 236-238. doi:10.1016/j.annals.2015.05.006

Danso, B. A., Xuhua, H., Addai, M., \& Mensah, I. A. (2018). Ranking Social Media Utilization among Tourists to Improve Marketing Innovation Using Bayesian Posterior Probability and Maximum Posterior Probability Procedure (MAP): Evidence from the Hospitality Industry in Ghana. Canadian Journal of Applied Science and Technology, 6(2), 2010-2217.

Ge, J. (2019). Social media-based visual humour use in tourism marketing: a semiotic perspective. The European Journal of Humour Research, 7(3), 6-25.

Gould, D. J., \& Nazarian, S. J. A. s. j. (2018). Social media return on investment: how much is it worth to my practice? , $38(5), 565-574$.

Gursoy, D., \& Sandstrom, J. K. (2016). An updated ranking of hospitality and tourism journals. Journal of Hospitality \& Tourism Research, 40(1), 3-18.

Hassan, S., Nadzim, S. Z. A., \& Shiratuddin, N. (2015). Strategic Use of Social Media for Small Business Based on the AIDA Model. Procedia - Social and Behavioral Sciences, 172, 262-269. doi:https://doi.org/10.1016/j.sbspro.2015.01.363

Hays, S., Page, S. J., \& Buhalis, D. (2013). Social media as a destination marketing tool: its use by national tourism organisations. Current Issues in Tourism, 16(3), 211-239. doi:10.1080/13683500.2012.662215

Henche, B. G. (2018). Use of social media as communication tools by the food markets of Madrid. Journal ofTourism Analysis, 25(1), 2-22.

Hilal, A. H., \& Alabri, S. S. (2013). Using NVivo for data analysis in qualitative research. International interdisciplinary journal of education, 2(2), 181-186.

Howison, S., Finger, G., \& Hauschka, C. (2015). Insights into the Web presence, online marketing, and the use of social media by tourism operators in Dunedin, New Zealand. Anatolia-International Journal of Tourism and Hospitality Research, 26(2), 269-283. doi:10.1080/13032917.2014.940357

Hsu, C., \& Ou Yang, S. (2013). Achieving online relationship marketing via tourism blogs: A social network perspective. Pacific Asia Journal of the Association for Information Systems, 5(4), 2. 
Huang, L. (2012). Social Media as a New Play in a Marketing Channel Strategy: Evidence from Taiwan Travel Agencies' Blogs. Asia Pacific Journal of Tourism Research, 17(6), 615-634. doi:10.1080/10941665.2011.635664

Hudson, S., \& Thal, K. (2013). The Impact of Social Media on the Consumer Decision Process: Implications for Tourism Marketing. Journal of Travel \& Tourism Marketing, 30(1-2), 156-160. doi:10.1080/10548408.2013.751276

Islam, M. T., \& Boro, A. (2019). Tourism Marketing via Social Media in India: The Most Effective Marketing Strategy to Evolve Indian Tourism. Journal of Tourism Intelligence and Smartness, 2(1), 39-46.

Jaelani, E., Erdinaya, L. K., Rohanda, R., \& Perbawasari, S. (2019). Islamic expression on instagram social media: Marketing communication strategies equestrian and archery tourism in indonesia. Library Philosophy and Practice (ejournal), 3578.

John, S., Larke, R., \& Kilgour, M. (2018). Applications of social media for medical tourism marketing: an empirical analysis. Anatolia-International Journal of Tourism and Hospitality Research, 29(4), 553-565. doi:10.1080/13032917.2018.1473261

Kaske, F., Kugler, M., \& Smolnik, S. (2012). Return on investment in social media--Does the hype pay off? Towards an assessment of the profitability of social media in organizations. Paper presented at the 2012 45th Hawaii International Conference on System Sciences.

Katsoni, V. (2014). The strategic role of virtual communities and social network sites on tourism destination marketing. e-Journal of Science \& Technology, 9(5).

Khuong, M. N., \& Huong, T. T. (2016). The Influence of Social Media Marketing on Vietnamese Traveller's Purchase Intention in Tourism Industry in Ho Chi Minh City. Journal of Economics, Business and Management, 4(4), $280-285$.

Kumar, P., Kumar, V., \& Mishra, J. M. (2015). Social media: A tool for tourism marketing. International Research Journal of Business and Management, 8(11), 1-6.

Latorre-Martinez, M. P., Iniguez-Berrozpe, T., \& Plumed-Lasarte, M. (2014). Image-focused social media for a market analysis of tourism consumption. International Journal of Technology Management, 64(1), 14. doi:10.1504/ijtm.2014.059234

Law, R., Leung, R., Lo, A., Leung, D., \& Fong, L. H. N. (2015). Distribution channel in hospitality and tourism: Revisiting disintermediation from the perspectives of hotels and travel agencies. International Journal of Contemporary Hospitality Management, 27(3), 431-452. doi:doi:10.1108/IJCHM-11-2013-0498

Lim, S., Saldana, A. Z., \& Saldana, P. E. Z. (2011). Do market oriented firms adopt Web 2.0 technologies? An empirical study in hospitality firms. International Entrepreneurship and Management Journal, 7(4), 465-477. doi:10.1007/s11365-011-0207-y

Lowry, P. B., Gaskin, J., Humpherys, S. L., Moody, G. D., Galletta, D. F., Barlow, J. B., \& Wilson, D. W. (2013). Evaluating journal quality and the association for information systems senior scholars' journal basket via bibliometric measures: Do expert journal assessments add value? MIS quarterly, 37(4), 993-1012.

Luque-Martinez, T., Faraoni, N., \& Dona-Toledo, L. (2019). Auditing the Marketing and Social Media Communication of Natural Protected Areas. How Marketing Can Contribute to the Sustainability of Tourism. Sustainability, 11(15), 1-23. doi:10.3390/su11154014

Matikiti, R., Mpinganjira, M., \& Roberts-Lombard, M. (2018). Application of the Technology Acceptance Model and the Technology-Organisation-Environment Model to examine social media marketing use in the South African tourism industry. South African Journal of Information Management, 20(1), 1-12. doi:10.4102/sajim.v20i1.790

Meredith, M. J. (2012). Strategic communication and social media: An MBA course from a business communication perspective. Business Communication Quarterly, 75(1), 89-95.

Mhizha, A., Nyaruwata, S., Munyanyiwa, T., \& Mandebvu, G. (2015). The adoption of Social Media Platforms in Tourism and Hospitality Marketing: The Case of Small and Medium Scale Enterprises (SMEs) in Harare. International journal of Development and Sustainability, 4(6), 635-649.

Moro, S., \& Rita, P. (2018). Brand strategies in social media in hospitality and tourism. International Journal of Contemporary Hospitality Management, 30(1), 343-364. doi:10.1108/ijchm-07-2016-0340

Oji, O. N. E., Iwu, C. G., \& Haydam, N. (2017). The use of social media marketing strategies by SMMEs in the hospitality sector in Cape Metropole, South Africa. African Journal of Hospitality, Tourism and Leisure, 6(1), 1-16.

Okoli, C., \& Schabram, K. (2010). A guide to conducting a systematic literature review of information systems research. Sprouts: Working Papers on Information Systems, 10(26), 1-49.

Oosterwyk, G., Brown, I., \& Geeling, S. (2019). A Synthesis of Literature Review Guidelines from Information Systems Journals. Paper presented at the Proceedings of 4th International Conference on the.

Park, J., \& Oh, I.-K. (2012). A Case Study of Social Media Marketing by Travel Agency: The Salience of Social Media Marketing in the Tourism Industry. International Journal of Tourism Sciences, 12(1), 93-106. doi:10.1080/15980634.2012.11434654 
Perera, G. R. P., I. (2016). Influence of Social Media Marketing on the Brand Image of Organizations in the Hospitality Industry of Sri Lanka. International Journal of Asian Business and Information Management, 7(1), 30-41. doi:10.4018/ijabim.2016010103

Rambe, P. (2017). Social media marketing and business competitiveness: evidence from South African tourism SMMEs. Problems and Perspectives in Management, 15(2), 411-423.

Rizk, N. T., Rifai, F. G., \& Jabr, S. M. (2018). The impact of social media marketing on tourism in Lebanon. International Journal of Multidisciplinary Research and Development, 5(5), 207-212.

Roque, V., \& Raposo, R. (2016). Social media as a communication and marketing tool in tourism: an analysis of online activities from international key player DMO. Anatolia-International Journal of Tourism and Hospitality Research, 27(1), 58-70. doi:10.1080/13032917.2015.1083209

Sabraz , N. S., \& Mubarak, k. M. (2015). Adoption of social media marketing by tourism product suppliers: a study in eastern province of Sri Lanka. European Journal of Business and Management, 7(7), 488-455.

Sahin, G. G., \& Sengün, G. (2015). The Effects of Social Media on Tourism Marketing: a Study among University Students. Management and Administrative Sciences Review, 4(5), 772-786.

Satghare, H., \& Sawant, M. (2018). Evaluation of social media marketing strategies of maharashtra tourism development corporation (india) from the tourists'perspectives. Journal of Tourism Economics and Applied Research, 1(1), 30-40.

Schryen, G. (2015). Writing qualitative is literature reviews - guidelines for synthesis, interpretation, and guidance of research. Communications of the Association for Information Systems, 37(1), 286 - 325.

Starkov, M., \& Safer, M. M. (2011). The Future is Now: The Emergence of The Customer Engagement Channel in Hospitality. Retrieved from https://www.hotelnewsresource.com/article52976.html

Stojanović, z., \& kurtić, s. (2019). Using social media as a channel of digital marketing in tourism sector in bosnia and herzegovina. Journal of Sustainable Development, 9(23), 81-92.

Templier, M., \& Paré, G. (2015). A framework for guiding and evaluating literature reviews. Communications of the Association for Information Systems, 37(1), 112 - 137.

Todua, N. (2018). Impact of Social Media Marketing on Consumer Behavior in the Georgian Tourism Industry. International Academy Journal Web of Scholar, 3(5 (23)), 11-16.

Trihas, N., Perakakis, E., Venitourakis, M., Mastorakis, G., \& Kopanakis, I. (2013). Social Media as a Marketing Tool for Tourism Destinations: The Case of Greek Municipalities. Journal of Marketing Vistas, 3(2), 38-48.

Tsiakali, K. (2018). User-generated-content versus marketing-generated-content: personality and content influence on traveler's behavior. Journal of Hospitality Marketing \& Management, 27(8), $946-972$. doi:10.1080/19368623.2018.1477643

Vaid, J., \& Kesharwani, S. (2018). Role of Big Data Analytics in Social Media Marketing of MICE Tourism. Global Journal of Enterprise Information System, 10(1), 55-61.

Zamani, S. Z. (2016). Examining the role of marketing models based on social networking in the tourism industry in Iran. International Journal of Humanities and Cultural Studies, 2(4), 1155-1168.

Zehrer, A., \& Grabmüller, A. (2012). Social media marketing in tourism education:Insights into the development and value of a social network site for a higher education institution in tourism. Journal of Vacation Marketing, 18(3), 221-228. doi: $10.1177 / 1356766712449368$ 